DOI https://doi.org/10.30525/978-9934-588-90-7-32

\title{
VIOLATIONS OF GRICEAN MAXIMS IN IRONIC SIMILES
}

\author{
Holtsova M. H. \\ PhD in Philology, Associate Professor \\ National University of Life and Environmental Sciences of Ukraine \\ Kyiv, Ukraine
}

One of the fastest-growing areas in linguistics is pragmatics. A key question in pragmatics research is the procedure of inferring implicatures. Implicature is a vital pragmatic element in the process of communication which bridges the gap between what is literally said and what is intentionally meant [3, p. 39]. In this research we are going to have a closer look at the ironic similes as the means of creating implicatures.

Irony is a species of figurative language, in which the intended meaning of an expression is usually some kind of opposite of the literal meaning. The literal meaning of an ironic expression typically echoes the words or assumed opinions of someone else, and is intended to mock or ridicule [1, p. 90]. Irony always has a certain pragmatic function and serves as a means of creating contrastive implicatures which we define as ironic.

The simile offers a highly productive form for the realization of memorable descriptions, so it is not surprising that similes are often used for humorous purposes. Ironic similes are based on the fact that the meaning of the word does not comply with the context of its use. In the ironic simile, the ground of the comparison is the antithesis of a salient feature, for example: as true as the sea burns; as like as an apple is to a lobster.

It should be mentioned that only a small part of the ironic similes are conventionalized and can be found in dictionaries (as seasonable as snow in harvest; as clear as mud; as like as chalk and cheese; as welcome as water in one's shoes) while most of them are innovative and creative, for example: as agile and nimble as an oil tanker; as fair as game of basketball is to short people; as lethal as a toy gun; as tender as having all your love letters returned; as healthy, like moving an asthmatic down a coal mine. The latter can be seen in the Bank of English corpus.

Illustrations for the study were taken from the Bank of English, A. Taylor's Proverbial Comparisons and Similes from California [9]; Similes Dictionary by E. Sommer and M. Sommer [7] and the internet resources.

In our paper we are going to analyse the ironic similes in regard to the maxims of Gricean Cooperative Principle with the aim of advocating the idea that ironic similes can be the means of conventional implicature creation. 
According to Grice [4; 5], the Cooperative Principle makes several requirements of speakers. They must "avoid providing less or more information than is required for the current purposes of the exchange" (The Quantity Maxim), "be truthful and avoid saying something lacking adequate evidence" (The Quality Maxim), "be relevant" (The Relation Maxim), "be brief and orderly and avoid ambiguity" (the Manner Maxim) [5, p. 26-27].

In the paper we are going to look at the violation of the above mentioned maxims in ironic similes. To illustrate this phenomenon, we will take three ironic similes: as fierce as a lion of Cotswold; as dangerous as a toothless wolf; as violent as an Essex lion.

The Manner Maxim is violated, as these ironic similes could be quite ambiguous, even incomprehensible. In order to decode the implicature one should know that the 'lion of Cotsword' is one of an English breed of large sheep having coarse, long wool; an Essex lion is nothing more than a calf. Without this knowledge an addressee will not be able to interpret the meaning correctly.

The Quantity maxim is violated due to the fact that polycomponent units (as fierce as a lion of Cotswold; as dangerous as a toothless wolf; as violent as an Essex lion) are used instead of monocomponent ones ('gentle', 'harmless', 'tame', 'mild').

Maxim of Quality is flouted and the ironic implicature is generated when the speaker deliberately says something that is false. In these ironic similes this is the case, as a sheep can't be fierce, a toothless wolf is not dangerous and a calf is absolutely harmless. Thus, the information sent by a speaker will be viewed as incorrect. The speaker is not trying to deceive the recipient in any way, which leads the listener to look for another set of meanings of the utterance.

The analysis and examples presented seem to give evidence showing that ironical utterances can not only flout the Quality Maxim but also the other three Gricean maxims. In most cases, ironical similes appear to be violating three or even all the maxims at the same time.

An interesting feature about ironic similes is the fact that their purpose is not to compare or to show similarity between two things, but instead they serve basically as a means of intensifying the denotative meaning of the comparant. For instance, the opposite meaning of the comparant 'useful' is intensified in the following similes as useful as windshield wipers on a submarine; as useful as the fifth wheel of a coach; as useful as a chocolate teapot; as useful as a feather duster in a snowstorm. However, one should know the structure of propositional implication of ironic similes $(\mathrm{P} \rightarrow \sim \mathrm{P}, \sim \mathrm{P} \rightarrow \mathrm{P}$ ), their ironic reinterpretation. Thus, inferring the ironic implicature from these similes, we understand that something is completely useless or unnecessary.

So, we can make a conclusion that ironic similes are the means of creating ironic implicatures. We define the ironic implicature as non-literal aspects of 122 
meaning that are not determined directly by the conventional structure of language expressions, but, on the contrary, are perceived with the opposite meaning. The ironic implicature is created as a result of intentional violation of maxims of the Cooperative Principle.

It should be noted that ironic implicatures appears not only in comparative idioms, but also in proverbs and sayings in the English language, for instance: That is as true as that the cat crew and the cock rocked the cradle; Things are as all right as soot is white; The wolf was sorry for the mare and ate her up with love and care; The crow bewails the sheep, and then eats it.

The research presented opens the prospects of further scientific research within pragmatics, which would focus on decoding ironic implicatures in English proverbs and saying.

\section{References:}

1. Cruse A. A glossary of semantics and pragmatics / Alan Cruse. Edinburgh : Edinburgh University Press Ltd., 2006. 198 p.

2. Goltsova M.G. Antiphrasis-Based Folk Similes in the English and Ukrainian Languages Vol. № 10, № 3, 2019. P. 45-51.

3. Goltsova M.G. The logic and pragmatic algorithm for the inferring euphemistic implicatures in the Ukrainian and English languages. International journal of philology. Vol. 10, № 2, 2019. P. 39-44

4. Grice H. P. Futher Notes on Logic and Conversation. Studies in the Way of Words. 1991. P. 41-57.

5. Grice H. P. Logic and Conversation. Studies in the Way of Words. 1991. P. 22-40.

6. Moon, R. Conventionalized as-similes in English: A problem case, International Journal of Corpus Linguistics, 13(1), 2008. P. 3-37.

7. Sommer E. Similes Dictionary / E. Sommer, M. Sommer. - Detroit; Michigan : Gale Research Company, 1988. 324 p.

8. Tartakovsky R., Fishelov D. Shen Y. Not as Clear as Day: On Irony, Humor, and Poeticity in the Closed Simile, Metaphor and Symbol, 34:3, 2019. P. 185-196.

9. Taylor, A. Proverbial comparisons and similes from California (Folklore Studies 3). Berkeley: University of California Press. 1954.

10. Veale, T., Hao, Y. Detecting Ironic Intent in Creative Comparisons. Proceedings of ECAI-2010, the 19th European conference on Artificial Intelligence. 2010. P. 765-770. 